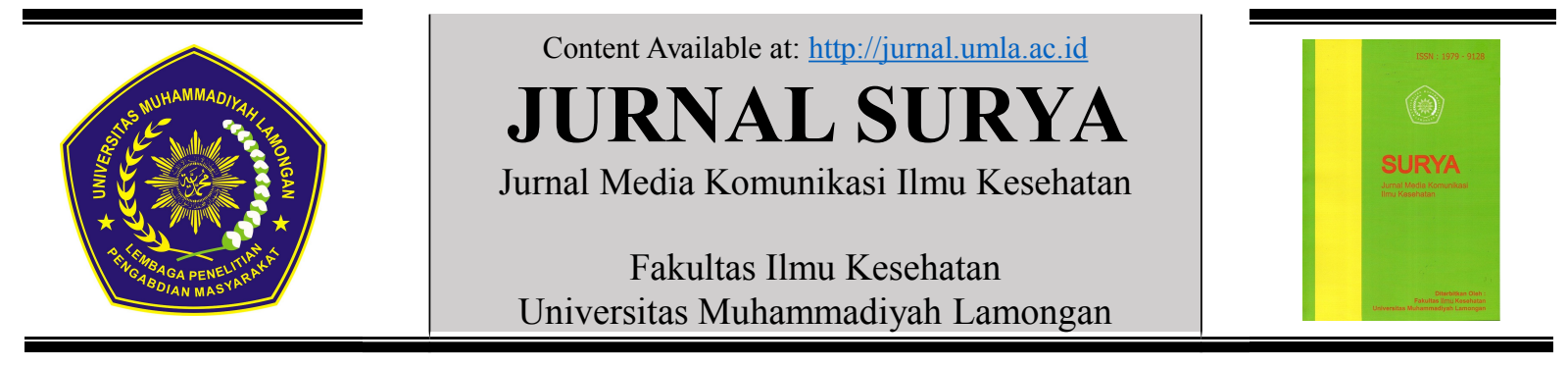

\title{
Tingkat Pengetahuan Masyarakat Tentang Swamedikasi yang Rasional di Lamongan
}

Devi Ristian Octavia ${ }^{1}$, Muhammad Syahrizal Zakaria ${ }^{2}$, Dian Nurafifah ${ }^{3}$

${ }^{1}$ Staf Pengajar Prodi D3 Farmasi Universitas Muhammadiyah Lamongan

${ }^{2}$ Mahasiswa Prodi D3 Farmasi Universitas Muhammadiyah Lamongan

${ }^{3}$ Staf Pengajar Prodi Kebidanan Universitas Muhammadiyah Lamongan

\section{ARTIKEL INFO}

\section{Article History:}

SM at 08-12-2019

$R V$ at $10-12-2019$

$P B$ at 24-12-2019

\section{Kata Kunci:}

Swamedikasi

Obat Rasional

\section{Korespondensi Penulis:} devioctavia1987@umla.ac.id , 081329995223

\begin{abstract}
ABSTRAK
Background: Pemakaian obat disebut rasional apabila pasien mendapatkan obat yang tepat untuk kebutuhan klinis, dengan dosis yang sesuai kebutuhan dalam jangka waktu yang cukup, juga dengan biaya yang terjangkau baik untuk individu ataupun masyarakat.
\end{abstract}

Objectives: Dalam pelaksanaannya, swamedikasi yang kurang tepat selain menimbulkan beban bagi pasien, juga menimbulkan masalah kesehatan tertentu yang tidak menguntungkan seperti resistensi obat, efek samping, interaksi obat, termasuk kematian.

Design: Desain penelitian yang digunakan pada penelitian ini adalah deskriptif Penelitian ini dilaksanakan pada bulan Februari sampai Juni 2019 di desa Sukodadi Kecamatan Sukodadi Kabupaten Lamongan.Populasi yang digunakan dalam penelitian adalah seluruh ibu di desa Sukodadi Kecamatan Sukodadi Kabupaten Lamongan, sedangkan metode pengambilan sampel yang digunakan adalah Simple Random Sampling, sehingga sampel yang digunakan dalam penelitian ini adalah sebagian ibu yang masuk kriteria inklusi, yakni $59 \mathrm{ibu}$.

Data Sources : Pengumpulan data dilakukan menggunakan alat obervasi berupa quetioner. Pertanyaan yang dituangkan dalam quetioner merupakan close ended quetion, dimana untuk jawaban yang benar diberi skor 1 dan jawaban yang salah skor 0 , kemudian dihitung persentase pengetahuan. Results: Hasil penelitian menunjukkan bahwa lebih dari sebagian masyarakat di desa Sukodadi kabupaten Lamongan memiliki pengetahuan yang baik tentang swamedikasi obat rasional.

Conclusions: Pengobatan yang rasional harus selalu di perhatikan oleh masyarakat agar mendapatkan efek terapi yang optimal. 
PENDAHULUAN

\begin{abstract}
Pengobatan sendiri (swamedikasi) didefinisikan sebagai pemilihan dan penggunaan obat oleh seseorang (atau anggota keluarga seseorang) untuk mengobati kondisi atau gejala yang dikenali atau didiagnosis sendiri. Beberapa manfaat dapat diperoleh dengan melakukan pengobatan sendiri yang sesuai, di antaranya upaya mengobati diri dari keluhan sakit lebih cepat, tanpa harus menemui tenaga kesehatan terlebih dahulu, dan menurunkan beban anggaran pemerintah untuk kesehatan (Ruiz, 2010). Penelitian di Irak melaporkan bahwa lebih dari $53 \%$ wanita melakukan swamedikasi. Selain itu Ameri, dkk (2017) juga melaporkan bahwa $92,4 \%$ siswa di Baghdad melakukan praktik swamedikasi untuk mengatasi keluhan nyeri yang dideritanya. Penelitian lain di melaporkan bahwa sebanyak $65,5 \%$ wanita di Brazil melakukan swamedikasi untuk obat-obatan analgesik, tetapi mereka kuran memahami penyakit kronis tidak boleh diobati sendiri.Kementrian Kesehatan Republik Indonesia tahun 2012 melaporkan bahwa sebanyak 44,4\% masyarakat Indonesia melakukan swamedikasi. Hasil Riskesdas (2013) mengungkapkan sebesar 35,2\% keluarga di Indonesia menyimpan obat di rumah (Harahap, Khairunnisa, \& Tanuwijaya, 2017).
\end{abstract}

Pemakaian obat disebut rasional menurut WHO jika pasien mendapatkan obat yang tepat untuk kebutuhan klinis, dengan dosis yang sesuai kebutuhan dalam jangka waktu yang cukup, juga dengan biaya yang terjangkau baik untuk individu ataupun masyarakat. Konsep tersebut berlaku dari pertama pasien datang menemui tenaga kesehatan, yang mencakup ketepatan penilaian kondisi pasien, tepat diagnosis, tepat indikasi, tepat jenis obat, tepat dosis, tepat cara dan lama pemberian, tepat informasi, dengan memperhatikan keterjangkauan harga, kepatuhan pasien, dan waspada efek samping. Pasien berhak mempertanyakan hal-hal tersebut kepada tenaga kesehatan.

Sambara, Yuliani Ni Nyoman \& Bureni Yantri, (2014) menyatakan meskipun obatbisa menyembuhkan suatu penyakit, akan tetapi ditemukan banyak kasus keracunan yang dialami seseorang karena penggunaan obat. Oleh sebab itu, dapat disimpulkan bahwa obat juga dapat bersifat racun. Obat bisa dimanfaatkan untuk menyembuhkan penyakit atau keluhan kesehatan jika dipakai dengan dosis yang sesuai, namun bila obat digunakan melebihi dosis yang dianjurkan, obat tersebut bisa menjadi racun. Jika dosis lebih rendah mengakibatkan efek penyembuhan tidak bisa dicapai.

Pengobatan sendiri dapat menjadi sangat beresiko, khususnya dalam kasus pengobatan sendiri yang tidak bertanggung jawab. Risiko potensial dari praktik pengobatan sendiri adalah diagnosa diri yang salah, keterlambatan dalam mencari nasihat medis ketika diperlukan, efek samping yang jarang tetapi parah, interaksi obat yang berbahaya, cara pemberian yang salah, dosis yang salah, pilihan terapi yang salah, penyembunyian penyakit parah dan risiko ketergantungan dan penyalahgunaan (Ruiz, 2010). Dalam pelaksanaannya, swamedikasi yang kurang tepat selain menimbulkan beban bagi pasien, juga menimbulkan masalah kesehatan tertentu yang tidak menguntungkan seperti resistensi obat, efek samping, interaksi obat, termasuk kematian (Rashid; Chhabra, 2019).

WHO meramalkan lebih dari 50\% obat yang diresepkan, dibagikan, dan dijual tidak tepat. Selain itu sekitar 50\% pasien tidak tepat dalam menkonsumsi obat. Berdasarkan survey awal yang telah dilakukan dengan metode wawancara terhadap masyarakat di desa Sukodadi Kabupaten Lamongan tentang penggunaan obat yang meliputi jenis obat yang sering digunakan oleh, dosis obat, lama penggunaan, apakah habis atau tidak, alasan untuk menghabiskan atau tidak menghabiskan obat yang digunakan. Hasil wawancara didapatkan informasi bahwa obat yang sering digunakan adalah antipiretik, analgesik, vitamin dan obat flu dan batuk. Ditemukan bahwa dari 10 orang, $40 \%$ menghabiskan obat yang sedang dipakai dan sisanya menghabiskan obat yang sedang dikonsumsi. Masyarakat menyatakan bahwa tidak menghabiskan obatnya karena merasa sudah sembuh dari penyakit yang dirasakannya. Selain itu, diketahui bahwa masih terdapat masyarakat yang tidak tahu takaran dosis obat yang sesuai dalam penggunaanya.

$\begin{array}{ccc} & \text { Pengetahuan tentang penggunaan } \\ \text { obat yang rendah } & \text { dikarenakan }\end{array}$ 
faktor keterbatasan pengetahuan masyarakat terhadap obat, pengguanaan obat dan kurangnya informasi tentang obat (Muharni, Aryani, \& Mizanni, 2015). Informasi obat yang tidak tercantum pada kemasan obat sering tidak diperhatikan dan dipahami dengan baik oleh masyarakat. Kurangnya pemahaman ini menyebabkan masyarakat bahkan menkonsumsi antibiotika tanpa menggunakan resep dari dokter sehingga memicu terjadinya resistensi antibiotika (Kemenkes, 2011).

Pengetahuan masyarakat tentang bahaya yang ditimbulkan obat dapat ditingkatkan dengan salah satu caranya yaitu menyediakan informasi seluas dan sebanyakbanyaknya tentang masalah obat. Pengawasan obat perlu dilakukan supaya tidak menimbulkan permasalahn dan penyalahgunaan obat. Swamedikasi di masyarakat juga perlu diperhatikan dengan cara memberikan informasi yang benar kepada masyarakat (Sambara et al., 2014).

\section{METODE}

Desain penelitian yang digunakan pada penelitian ini adalah deskriptif yang bertujuan untuk mendiskripsikan atau menggambarkan tingkat pengetahuan masyarakat tentang penggunaan obat yang rasional. Penelitian ini dilaksanakan pada bulan Februari sampai Juni 2019 di desa Sukodadi Kecamatan Sukodadi Kabupaten Lamongan.Populasi yang digunakan dalam penelitian adalah seluruh ibu di desa Sukodadi Kecamatan Sukodadi Kabupaten Lamongan, sedangkan metode pengambilan sampel yang digunakan adalah Simple Random Sampling, sehingga sampel yang digunakan dalam penelitian ini adalah sebagian ibu yang masuk kriteria inklusi, yakni 59 ibu.

Pengumpulan data dilakukan menggunakan alat obervasi berupa quetioner. Pertanyaan yang dituangkan dalam quetioner merupakan close ended quetion, dimana untuk jawaban yang benar diberi skor 1 dan jawaban yang salah skor 0 . Persentase pengetahuan dihitung berdasarkan kriteria sebagai berikut:

$\mathrm{P}=\frac{S p}{S m} \times 100 \%$
Dimana

$\mathrm{P} \quad$ : Persentase

Sp : : Skor Perolehan

Sm : Skor Maksimal

Selanjutnya data diklasifikasi menurut Nursalam (2014) yaitu pengetahuan baik 76-100\%, pengetahuan cukup 56$75 \%$, pengetahuan kurang $<55 \%$.

\section{HASIL PENELITIAN}

Sampel dalam penelitian ini adalah masyarakat di desa Sukodadi adalah responden yang memenuhi kriteria inklusi antara lain wanita yang berusia 18-50 tahun, sudah menikah, bersedia untuk diteliti dan mau menandatangani Informed Consent. Sedangkan responden yang tidak bisa dijadikan sampel adalah yang tidak bersedia mengisi lembar quetioner, tidak bisa membaca dan menulis dan bila quetioner nya tidak terbaca dengan jelas. Dari hasil penelitian yang telah dilakukan didapatkan responden sejumlah 59 orang yang merupakan perwakilan anggota keluarga. Adapun karakteristik responden yang didapatkan berdasarkan hasil penelitian ini disajikan pada tabel 1.

Tabel 1 Karakteristik Responden

\begin{tabular}{llcc}
\hline No & Data Umum & F & \% \\
\hline \multicolumn{4}{l}{ Usia (tahun) } \\
1 & $21-35$ & 16 & 27,1 \\
2 & $>35$ tahun & 43 & 72,9 \\
\hline \multicolumn{4}{l}{ Pendidikan } \\
1 & SD/Sederajat & 5 & 8,5 \\
2 & SMP/Sederajat & 15 & 25,4 \\
3 & SMA/Sederajat & 32 & 54,2 \\
4 & Perguruan Tinggi & 7 & 11,9 \\
\hline \multicolumn{4}{c}{ Pekerjaan } \\
1 & IRT & 15 & 42,4 \\
2 & Wiraswasta & 28 & 27,5 \\
3 & Pegawai Swasta & 6 & 10,1 \\
\hline \multicolumn{4}{c}{ Berdasarkan tabel diatas diketahui } \\
bahwa sebagian besar responden berusia $>35$ \\
tahun (72,9\%) dan hampir sebagian ibu \\
berusia 21-35 tahun (27,1\%). Data tentang \\
pendidikan menunjukkan bahwa sebagian \\
besar responden \\
SMA/Sederajat (54,2\%) dan sebagian kecil \\
beprendidikan SD/Sederajat (8,5\%). \\
Sedangkan pekerjaan responden hampir
\end{tabular}


sebagian responden mempunyai pekerjaan sebagai wiraswasta $(47,5 \%)$ dan sebagian kecil mempunyai pekerjaan sebagai pegawai swasta.

Tabel 2 Distribusi tingkat Pengetahuan masyarakat tentang Penggunaan Obat Rasional

\begin{tabular}{llcc}
\hline No & Pengetahuan & F & \% \\
\hline 1 & Baik & 39 & 66,1 \\
2 & Cukup & 16 & 27,1 \\
3 & Kurang & 4 & 6,8 \\
\hline & Jumlah & $\mathbf{5 9}$ & $\mathbf{1 0 0}$ \\
\hline
\end{tabular}

Berdasarkan tabel 2 diatas diketahui bahwa sebagian besar responden mempunyai pengetahuan baik $(66,1 \% 0$ dan sebagian kecil $(6,8 \%)$ adalah kurang.

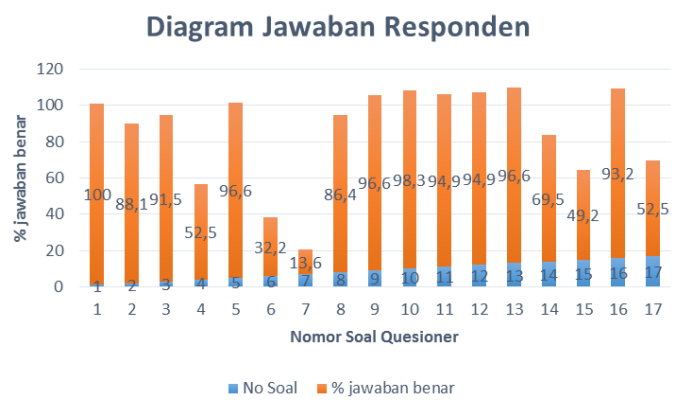

Gambar 1. Diagram data jawaban responden

Dalam penelitian ini indikator yang digunakan untuk mengukur pengetahuan masyarakat tentang penggunaan obat meliputi pengertian obat rasional (quesioner nomor 1 dan 2), penggolongan obat (quesioner nomor 3 dan 4), indikasi obat (quesioner nomor 5), kontraindikasi obat (quesioner nomor 6), dosis obat (quesioner nomor 7 dan 8), efek samping dan perhatian obat (quesioner nomor 9,10 dan 11) serta mutu obat (quesioner nomor 12), tindak lanjut (quesioner nomor 13), lama pemberian dan interval waktu penggunaan obat (quesioner 14 dan 15), cara oemberian (quesioner 16), informasi obat (quesioner 17).

\section{PEMBAHASAN}

Hasil penelitian yang disajikan pada tabel 2 menunjukkan bahwa dari seluruh responden tercatat bahwa lebih dari sebagian masyarakat $(66,1 \%)$ memiliki pengetahuan baik tentang penggunaan obat rasional.
Pengetahuan seseorang bisa dipengaruhi oleh beberapa faktor, antara lain usia, jenis kelamin, tingkat pendidikan, tingkat pendapatan, paparan informasi, kosultasi dengan tenaga kesehatan juga sosial budaya (Ar-Rasily \& Dewi, 2016).

Pengetahuan bisa didapat seseorang dengan beberapa cara, yaitu brdasarkan pengalaman pribadi, belajar dari_kesalahan yang pernah dilakukan, adanya suatu otoritas atau kekuasaan yang mengharuskan seseorang melakukan sesuatu, juga logika yang mengharuskan seseorang mampu berfikir dan memiliki nalar terhadap sesuatu (Liana, 2017). Pengetahuan mengenai penggunaan obat rasional bisa diperoleh dari edukasi atau paparan dari tenaga kefarmasian baik itu di apotek, puskesmas, rumah sakit atau tempat pelayanan kesehatan lainnya. Masyarakatnya hendaknya aktif untuk menggali informasi sebanyak-banyaknya kepada petugas kefarmasian agar terapi penggunaan obat dapat berjalan sesuai dengan harapan.

Ihsan, Sabarudin, Leorita, Syukriadi, \& Ibrahim (2017) menyatakan dalam pelayanan kesehatan, obat memainkan peran yang sangat penting dalam tercapainya kesehatan pasien, namun penggunaan obat yang rasional masih menjadi masalah terbesar dalam tercapainya terapi yang efektif dan efisien. Menurut Modul obat rasional yang diterbitkan oleh Kemenkes (2011), kriteria penggunaan obat rasional antara lain: tepat diagnosis, tepat indikasi penyakit, tepat memilih obat, tepat dosis, tepat penilaian kondisi pasien, waspada terhadap efek samping, efektif, aman, mutu terjamin, harga terjangkau, tersedia setiap saat, tepat tindak lanjut, dan tepat dispensing (penyerahan obat). Pemakaian obat yang rasional sangat penting sebagai upaya tercapainya kualitas hidup dan kesejahteraan masyarakat yang lebih baik. Penggunaan obat rasional akan memberikan manfaat pada masyarakat baik dari segi ekonomi ataupun peningkatan derajat kesehatan yang mendorong pada produktivitas kerja masyarakat agar mengarah kepada terbangunnya ketahanan nasional (Ihsan et al., 2017). Penggunaan obat yang tidak rasional bisa mengakibatkan pemborosan biaya dan yang lebih buruk bisa menyebabkan 
resistensi antibiotika (Kemenkes, 2011). Penggunaan obat yang tidak rasional berpotensi besar dalam kejadian medication error sehingga menyebabkan beban pasien meningkat, menambah pengeluaran anggaran, juga efek samping serta interaksi penggunaan obat semakin menngkat resikonya (Mutmainah, Setyati, \& Handasari, 2014).

Tabel 1 menunjukkan bahwa sebagian responden berusia $>35$ tahun. Mayoritas responden yang berusia produktif membuat daya tangkap dan pola pikir seseorang semakin berkembang sehingga semakin mudah untuk menggali informasi tentang obat rasional. Dalam teorinya, umur berpengaruh terhadap perkembangan daya tangkap dan pola pikir seseorang, semakin tua umur seseorang maka prosesproses perkembangan mentalnya bertambah baik, akan tetapi pada usia tertentu, bertambahnya proses perkembangan mental ini tidak secepat seperti ketika berusia belasan tahun. Bertambahnya usia seseorang dapat mempengaruhi pertambahan pengetahuan yang diperolehnya (Ar-Rasily \& Dewi, 2016). Mayoritas umur responden yang produktif telah memiliki pengalaman yang cukup banyak dalam hal pengobatan. Hal itu bisa menjadi penyebab mengapa banyaknya responden yang didominasi umur tersebut. Responden yang dipilih dalam peneltian ini adalah perwakilan anggota keluarga, dan dipilih berdasarkan jenis kelamin yaitu seorang perempuan, dimana dalam hal ini yang diambil sebagai sampel penelitian adalah ibu rumah tangga. Oktarlina et al., (2018) menyatakan bahwa perempuan lebih peduli terhadap kesehatan jika dibandingkan dengan laki-laki. Seorang ibu rumah tangga biasanya menjadi desision maker dalam penggunaan obat ketika terdapat anggota keluarga yang mengalami keluhan kesehatan. Seorang ibu berupaya untuk memberikan obat berdasarkan pengalaman pribadinya, pengalaman dari anggota keluarga yang lain juga informasi yang didapat baik dari media cetak, audiovisual maupun edukasi yang diperolehnya dari tenaga kesehatan.

Berdasarkan faktor pendidikan, sebagian responden berpendidikan SMA atau sederajat. Teori menyatakan bahwa pendidikan merupakan suatu kegiatan atau proses pembelajaran dalam mengembangkan dan meningkatkan kemampuan tertentu sehingga sasaran pendidikan itu dapat berdiri sendiri. Tingkat pendidikan juga menentukan mudah atau tidaknya seseorang untuk menyerap dan memahami pengetahuan yang mereka dapatkan, pada umumnya semakin tinggi pendidikan seseorang, maka semakin baik pula pengetahuanya (Ar-Rasily \& Dewi, 2016). Sebagian responden yang berpendidikan tinggi mengakibatkan informasi tentang penggunaan obat rasional lebih mudah untuk diterima.

Pada faktor pekerjaan responden, hampir sebagian responden tidak bekerja atau sebagai ibu rumah tangga. Seorang ibu rumah tangga merupakan pembuat keputusan dalam hal penggunaan obat. Pengetahuan ibu rumah tangga biasanya didapatkan dari hasil bersosialisasi dengan warga sesama lingkungan baik itu dalam kegiatan PKK, pengajian atau kegiatan sosial lainnya. Faktor pekerjaan dan pengetahuan seseorang biasanya dihubungkan dengan adanya sosialisasi atau pergaulan antara sesama masyarakat. Dengan banyak berkumpul dan bersosialisasi masyarakat akan saling bertukar pengalaman dan cerita termasuk tentang riwayat pengobatan sendiri atau swamedikasi yang telah dilakukannya. Selain itu pekerjaan akan berdampak pada pendapatan seseorang. Dalam teorinya, tingkat pendapatan_seseorang akan mempengaruhi tingkat pengetahuannya, dimana seseorang dengan pendapatan yang tinggi akan menentukan fasilitas kesehatan yang diperlukan sehingga lebih mudah dalam menggali informasi pengobatan. Namun penelitian yang dilakukan oleh Mutmainah et al., (2014) membuktikan bahwa tingkat pendapatan tidak berpengaruh terhadap pengetahuan seseorang. Hal ini sesuai dengan hasil penelitian yang telah dilakukan bahwa walaupun lebih dari sebagian responden bekerja sebagai ibu rumah tangga tetapi lebih dari sebagian memiliki pengetahuan yang baik tentang penggunaan obat rasional. Hal tersebut karena pengetahuan bisa didapatkan dari mana saja misalnya membaca buku, brosur ataupun majalah, informasi dari media sosial, hp, televisi ataupun internet.

Pada quesioner tentang pengertian pengguanaan obat butir ke satu yaitu "Memilih obat yang tepat adalah sesuai dengan penyakit yang diderita", pada pernyataan ini $100 \%$ responden menjawab 
dengan benar. Sedangkan pada pernyataan ke dua yaitu "Obat yang baik adalah obat yang harganya mahal". Hampir seluruh responden menjawab dengan benar pernyataan tersebuyt yaitu $88,1 \%$. Harga dari suatu obat tidaklah berbanding lurus dengan kualitasnya. Ada beberapa obat yang walaupun harganya lebih murah tetapi memiliki khasiat atau manfaat setara dengan obat yang harganya jauh lebih mahal, contohnya adalah obat generik. Menurut Kemenkes, (2011), penggunaan obat dikatakan rasional adalah apabila pasien menerima obat sesuai dengan kebutuhannya dengan periode waktu yang cukup dan dengan harga yang seekonomis mungkin.

Indikator yang diukur selanjutnya adalah tentang penggolongan obat. Pada quetioner nomor 3 berbunyi "untuk mendapatkan obat yang aman bisa dibeli di apotek atau toko obat" Hampir seluruh responden menjawab benar pernyataan tersebut. Masyarakat cukup menyadari bahwa mendapatkan obat yang baik dan terjamin kualitasnya sebaiknya di apotek atau toko obat berijin. Hal ini karena di apotek atau toko obat berijin terdapat tenaga kefarmasian yang akan membantu memberikan informasi terkait penggunaan obat. Selain itu, obat yang dijual di apotek ataupun toko obat berijin terjamin keaslian dan keamanannya karena prosedur resmi dalam pengadaan obat tersebut telah terverivikasi.Pada poin 4 quesioner menyatakan "Obat dengan lambang hijau dan biru bisa dibeli tanpa resep dokter". Sebagian menjawab dengan benar (52\%). Menurut Umi Athiyah (2011) obat bebas adalah obat yang tersedia di apotek dan masyarakat bisa mendapatkannnya tanpa menggunakan resep dokter, obat ini di tandai dengan logo warna hijau dengan garis tepi hitam. Sedangkan obat bebas terbatas yang ditandai dengan logo berwarna biru dengan garis tepi hitam juga bisa dibeli tanpa menggunakan resep dokter di apotek atau toko obat. Namun obat golongan bebas terbatas dalam penggunaannya harus memperhatikan peringatan yang tertera pada brosur atau label obat tersebut. Indikator tentang indikasi obat tertuang pada quesioner nomor 5 yaitu "Paracetamol adalah obat yang digunakan untuk deman dan nyeri”. Hampir seluruh responden $(96,9 \%)$ menjawab benar. Dalam Kemenkes (2011) dijelaskan bahwa tepat indikasi adalah apabila pasien menerima obat sesuai dengan keluhan yang dirasakan sehingga ada indikasi yang sesuai untuk penggunaan obat yang dijalaninya.

Indikator tentang kontraindikasi dari obat tertuang dalam quesioner nomor 6 yaitu "semua obat aman digunakan ibu hamil dan menyusui. Responden yang menjawab benar sebesar 92,3\%. Masyarakat cukup memahami bahwa tidak semua obat aman digunakan untuk ibu hamil atau menyusui karena akan berimbas pada janin atau anak yang sedang disusuinya. Penggunaan obat harus menyesuaikan dengan indikasi pasien dengan memperhatikan kontraindikasi obat, komplikasi pada keadaan patofisologis ataupun fisiologis dari pasien. Indikator dosis obat (quesioner nomor 7 dan 8) yaitu "dosis anak adalah setengah dari dosis dewasa". Pada quetioner ini hanya sebagian kecil responden yang menjawab benar (13,6\%). Tidak semua anak-anak menerima dosis setengah dari dosis dewasa, hal tesebut ditentukan oleh berat badan, usia dan faktor fisiologi dari anak-anak. Quesioner nomor 8 yaitu "jika minum obat pagi hari, siang hari langsung inum obat 2 sekaligus". Pada pernyataan ini sebanyak $86,5 \%$ responden menjawab benar. Kemenkes (2011) menjabarkan tepat dosis, cara dan lama pemberian obat sangat berpengaruh terhadap efek terapi obat. Pemberian dosis yang kurang sesuai menjadikan obat tidak mampu memberikan efek terapi seperti yang diharapkan. Pengukuran dosis biasanya berhubungan pula dengan lama penggunaan obat dan interval penggunaan obat seperti yang tertuang pada quesioner nomor 14 dan 15. Masyarakat cukup memahami bahwa obat yang diminum $3 \mathrm{x}$ sehari berarti diminum dengan interval tiap 8 jam.

Indikator mengenai efek samping dan perhatian terhadap penggunaan obat tertuang pada quesionr nomor 9, 10 dan 11. Berturut turut hampir seluruh responden menjawab benar. Pemberian obat potensial menimbulkan efek samping, yaitu efek tidak diinginkan yang muncul akibat pemggunaan obat dengan dosis terapi. Umumnya efek samping dapat terjadi selang beberapa saat setelah meminum obat. Efek samping yang terjadi akibat obat bisa beragam, misalnya gatal, bercak merah atau panas, pusing, mual atau bahkan diare dan konstipasi. Masyarakat harus memahami jika 
efek samping yang timbul sangat mengganggu, maka dihimbau untuk menghentikan konsumsi obat dan berkonsultasi ke tenaga kesehatan sesegera mungkin (Kemenkes, 2011).

Quesioner nomor 12 dan 13 berisi tentang mutu obat dan tindak lanjut tentang penggunaan obat, hampir seluruh responden menjawab benar seperti dapat dilihat pada diagram 1. Masyarakat harus memperhatikan obat yang sedang digunakannya, apakah masih terjamin mutunya, seperti obat belum kadaluarsa, kemasan obat masih baik dan fisik obat belum berubah. Mengkonsumsi obat yang telah rusak akan berakibat pada efek obat yang tidak diinginkan dan sangat berbahaya. Selain itu, masyarakat harus mempunyai rencana tindak lanjut, jika swamedikasi yang dilakukannya tidak menghasilkan efek seperti yang diharapkan. Misalnya sudah mengkonsumsi obat selama 3 hari, namun tidak ada perubahan gejala, maka masyarakat hendaknya menghubungi dokter.

Quesioner nomor 16 dan 17 berisi tentang bagaimana cara meminum obat yang baik untuk menghindari terjadinya efek obat yang tidak diinginkan atau interaksi obat. Adapun pernyataan yang tertuang dalam quesioner adalah "minum obat boleh dengan kopi, susu atau teh" hampir semua responden menjawab dengan benar. Minum obat lebih baik dengan menggunakan segelas air putih untuk menghindari terjadinya interaksi obat dengan makanan atau minuman.

\section{KESIMPULAN}

Lebih dari sebagian masyarakat di desa Sukodadi kabupaten Lamongan memiliki pengetahuan yang baik tentang swamedikasi obat rasional.

\section{DAFTAR PUSTAKA}

Ar-Rasily, O., \& Dewi, P. (2016). Faktor Faktor Yang Mempengaruhi Tingkat Pengetahuan Orang Tua Mengenai Kelainan Genetik Penyebab Disabilitas Intelektual Di Kota Semarang. Jurnal Kedokteran Diponegoro, 5(4), 14221433.

Harahap, N. A., Khairunnisa, K., \& Tanuwijaya, J. (2017). Patient knowledge and rationality of selfmedication in three pharmacies of Panyabungan City, Indonesia. Jurnal Sains Farmasi \& Klinis, 3(2), 186. https://doi.org/10.29208/jsfk.2017.3.2.1 24

Ihsan, S., Sabarudin, Leorita, M., Syukriadi, A. S. Z., \& Ibrahim, M. H. (2017). Evaluasi Rasionalitas Penggunaan Obat Ditinjau dari Indikator Peresepan Menurut World Health Organization (WHO) di Seluruh Puskesmas Kota Kendari Tahun 2016. Issn, 5, 402-409. https://doi.org/10.1021/la303091k

Kemenkes. (2011). Modul Penggunaan Obat Rasional. Jakarta.

Liana, Y. (2017). Analisis faktor-faktor yang mempengaruhi keluarga dalam penggunaan obat tradisional sebagai swamedikasi di Desa Tuguharum Kecamatan Madang Raya WHO (World Health Organization ) merekomendasikan Hasil Susenas tahun 2007 menunjukan di memilih cara pengobat. 4(3), 121-128.

Muharni, S., Aryani, F., \& Mizanni, M. (2015). Gambaran Tenaga Kefarmasian Dalam Memberikan Informasi Kepada Pelaku Swamedikasi di Apotek-Apotek Kecamatan Tampan, Pekanbaru. Jurnal Sains Farmasi \& Klinis, 2(1), 47. https://doi.org/10.29208/jsfk.2015.2.1.4 6

Mutmainah, N., Setyati, P., \& Handasari, N. (2014). Evaluation of the Use and Effectiveness of Antibiotics for Prophylactic in Patients with Cesarean Section at Hospitals in Surakarta in 2010. Indonesian Journal of Clinical Pharmacy, 3(2), 44-49. https://doi.org/10.15416/ijcp.2014.3.2.4 4

Nursalam. (2014). Metodologi Penelitian Ilmu Keperawatan Pendekatan Praktis (3rd ed.; S. Medika, ed.). Jakarta.

Oktarlina, R. Z., Tarigan, A., Carolia, N., Utami, E. R., Farmakologi, B., Kedokteran, F., \& Lampung, U. (2018). 
Hubungan Pengetahuan Keluarga dengan Penggunaan Obat Tradisional di Desa Nunggalrejo Kecamatan Punggur Kabupaten Lampung Tengah The Relation Of Family Knowledge With Traditional Medicine Use At Nunggalrejo Village Punggur District Central Lampung Regency. 2, 42-46.

Rashid; Chhabra, M. K. A. U. A. G. S. (2019). Prevalence and Predictors of SelfMedication Practices in India: A Systematic Literature Review and MetaAnalysis. Curr Clin Pharmacol, 21(November).

https://doi.org/10.2174/1574884714666 191122103953.

RK, A.-A. R. A. A.-B. H. L. (2017). Prevalence of self-medication among university students in Baghdad: a crosssectional study from Iraq. East Mediterr Health, 23(2), 87-93. https://doi.org/10.26719/2017.23.2.87

Ruiz, M. (2010). Risks of Self-Medication Practices. Current Drug Safety, 5(4), 315-323.

https://doi.org/10.2174/1574886107922 45966

Sambara, J., Yuliani Ni Nyoman;, \& Bureni Yantri. (2014). JURNAL 2 Tingkat Pengetahuan dan Pemahaman Masyarakat tentang Penggunaan Obat yang Benar.pdf. Health Information Journal, 12(1), 500-709.

Umi Athiyah. (2011). Buku Ajar Preskripsi Obat dan Resep Jilid 1. Airlangga University Press. 